\title{
Technical Note: Synthesis of isoprene atmospheric oxidation products: isomeric epoxydiols and the rearrangement products cis- and trans-3-methyl-3,4-dihydroxytetrahydrofuran
}

\author{
Z. Zhang, Y.-H. Lin, H. Zhang, J. D. Surratt, L. M. Ball, and A. Gold \\ Department of Environmental Sciences and Engineering, Gillings School of Global Public Health, \\ The University of North Carolina at Chapel Hill, NC, 27599-7431, USA
}

Correspondence to: Z. Zhang (zhenfaz@email.unc.edu)

Received: 2 May 2012 - Published in Atmos. Chem. Phys. Discuss.: 7 June 2012

Revised: 28 August 2012 - Accepted: 4 September 2012 - Published: 21 September 2012

\begin{abstract}
Isoprene epoxydiol (IEPOX) isomers are key gas-phase intermediates of isoprene atmospheric oxidation. Secondary organic aerosols derived from such intermediates have important impacts on air quality and health. We report here convergent and unambiguous pathways developed for the synthesis of isomeric IEPOX species and the rearrangement products cis- and trans-3-methyl-3,4dihydroxytetrahydrofuran in good yield. The availability of such compounds is necessary to expedite research on isoprene atmospheric oxidation mechanisms and subsequent aerosol formation as well as the toxicological properties of the aerosols.
\end{abstract}

\section{Introduction}

Isoprene (2-methyl-1,3-butadiene, 1), the most abundant non-methane biogenic hydrocarbon emitted into the Earth's atmosphere (Guenther et al., 2006), undergoes extensive atmospheric oxidation. The resulting secondary organic aerosol (SOA) contributes significantly to the overall atmospheric aerosol budget (Claeys et al., 2004; Carlton et al., 2009), which affects regional air quality and global climate. Isoprene-derived SOA is also a major contributor to fine particulate matter $\left(\mathrm{PM}_{2.5}\right)$, which adversely impacts respiratory and cardiovascular systems of exposed populations (Pope III and Dockery, 2006). Under low nitric oxide (NO) conditions, gas-phase oxidation of isoprene yields four epoxydiol (IEPOX) isomers (Eddingsaas et al., 2010; Lin et al., 2012; Paulot et al., 2009; Surratt et al., 2010; Wang et al.,
2005) (Fig. 1; IEPOX-1-4). Although epoxides have been suggested as possible precursors for SOA (Paulot et al., 2009; Surratt et al., 2010), the reaction pathways leading to aerosol formation are unknown. The gas-phase formation of the IEPOX isomers in high yield can provide suitable precursors for SOA and elucidation of the reaction pathways involved in this chemistry will contribute to resolving an outstanding puzzle in atmospheric aerosol chemistry. Recently, we have synthesized the four IEPOX isomers and in a series of controlled dark chamber studies have demonstrated that their reactive uptake onto pre-existing acidic seed aerosols yielded SOA (Lin et al., 2012). We have in addition, identified two previously unreported direct rearrangement products of the IEPOX isomers on uptake by acidic seed particles, $\mathrm{cis}$ and trans-3-methyl-3,4-dihydroxytetrahydrofuran (Lin et al., 2012; Chan et al., 2010). Comparison of the chemical composition of the IEPOX-derived SOA with that of fine aerosol samples collected from the rural Southeastern US has confirmed the atmospheric relevance of our chamber findings, providing substantial support for the role of IEPOX in forming organic aerosol in the troposphere (Lin et al., 2012).

Our published study (Lin et al., 2012) demonstrates that availability of authentic, pure and rigorously-characterized intermediates and standards is critical for investigations into the generation and subsequent reactions of the IEPOX isomers leading to SOA and the identification and quantitation of aerosol components. In addition, availability of these compounds is essential for evaluation of their toxicological properties in order to assess the impact of isoprenederived aerosols on human health. The IEPOX isomers and 


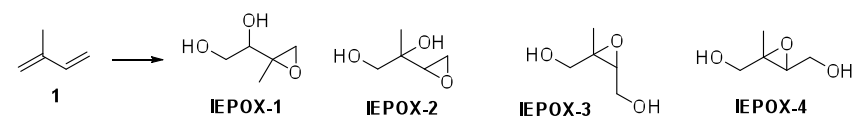

Fig. 1. Structures and abbreviations for IEPOX isomers.

other putative components of isoprene-derived SOA are not at present commercially available and no streamlined synthetic routes to these compounds in quantity and high purity have yet been reported. Investigation into the chemistry of IEPOX has to date relied upon the simpler surrogate butadiene epoxydiol (Eddingsaas et al., 2010; Paulot et al., 2009; Surratt et al., 2010) to explore reaction pathways, and on surrogate standards for quantitation of key isoprene tracers. We report here the convenient synthesis of regioisomers IEPOX$\mathbf{1 - 4}$, and the isomeric tetrahydrofurans that are the immediate rearrangement products of IEPOX isomers on contact with acidic seed aerosols (Lin et al., 2012).

\section{Experimental section}

\subsection{Instrumentation}

All the nuclear magnetic resonance (NMR) spectra were recorded on a Varian INOVA $400 \mathrm{MHz}$ spectrometer, with chemical shifts reported in ppm relative to tetramethylsilane. Splitting patterns are reported as: $\mathrm{m}$ (multiplet), s (singlet), $\mathrm{d}$ (doublet), t (triplet) and dd (doublet of doublets). Gas chromatography/electron impact ionization mass spectrometry (GC/EI-MS) was performed with prior trimethylsilylation. Samples were trimethylsilylated by treatment with $\mathrm{N}, \mathrm{O}$ bis(trimethylsilyl)trifluoroacetamide and trimethylchlorosilane (BSTFA + TMCS) $(99: 1,100 \mu \mathrm{v} / \mathrm{v}$, Supelco) and pyridine $\left(50 \mu\right.$ anhydrous, $99.8 \%$, Sigma-Aldrich) at $70{ }^{\circ} \mathrm{C}$ for $1 \mathrm{~h}$, and analyzed on a Hewlett-Packard (HP) 5890 Series II Gas Chromatograph with an Econo-Cap ${ }^{\mathrm{TM}}-\mathrm{EC}^{\mathrm{TM}}$ Capillary Column $(30 \mathrm{~m} \times 0.25 \mathrm{~mm}$ i.d.; $0.25 \mu \mathrm{m}$ film thickness $)$ coupled to an HP 5971A Mass Selective Detector. Operating conditions and temperature program were as described previously (Surratt et al., 2010).

\subsection{IEPOX-1 (erythro- and threo- 1-(2-methyloxiran-2- yl)ethane-1,2-diol)}

To 2-methyl-2-vinyloxirane (2, $1.3 \mathrm{~g}, 14.8 \mathrm{mmol}$, Alfa Aesar) in acetone $\left(50 \mathrm{ml}\right.$, Fisher Scientific), $\mathrm{OsO}_{4}(2 \mathrm{ml}$, $1 \%$ in water, Aldrich) and $N$-methylmorpholine $N$-oxide (3.46 g. $29.6 \mathrm{mmol}$, Aldrich) were added and the reaction stirred at room temperature (RT) until the starting material was completely consumed. Progress was monitored by the disappearance of the three-proton vinylic signals $(5.64 \mathrm{ppm}, \mathrm{dd}, J=17.6,10.7 \mathrm{~Hz} ; 5.35 \mathrm{ppm}, \mathrm{dd}, J=$ 17.6, $1.1 \mathrm{~Hz} ; 5.23 \mathrm{ppm}, \mathrm{dd}, J=10.7,1.1 \mathrm{~Hz})$ in the ${ }^{1} \mathrm{H}$ NMR spectrum of reaction mixture aliquots. Upon com- pletion, the reaction mixture was diluted with ethyl acetate (50 ml, Acros), quenched with saturated $\mathrm{Na}_{2} \mathrm{~S}_{2} \mathrm{O}_{3}(2 \mathrm{ml}$, Aldrich), dried over anhydrous $\mathrm{Na}_{2} \mathrm{SO}_{4}$ (Acros) and filtered. The filtrate was concentrated under reduced pressure, and the residue purified by flash chromatography $\left(\mathrm{SiO}_{2}-\right.$ Aldrich, diethyl ether - Fisher) to give the mixture of enantiomeric IEPOX-1 diastereomers as a colorless oil $(1.19 \mathrm{~g}$, $68 \%)$. IEPOX-1 is a racemic mixture of diasteromers erythro-IEPOX-1 ([(2'R)-1S $] /\left[\left(2^{\prime} S\right)-1 \mathrm{R}\right]-1-(2-m e t h y l o x i r a n y l)-$ 1,2-ethanediol) and threo-IEPOX-1 ([(2'S)-1S $] /\left[\left(2^{\prime} \mathrm{R}\right)-1 \mathrm{R}\right]-$ 1-(2-methyloxiranyl)-1,2-ethanediol). (erythro/threo, $2: 1$ ). GC/EI-MS. $m / z, 231,217,205,191,177,159,147$. erythoIEPOX-1: ${ }^{1} \mathrm{H}$ NMR $\left(400 \mathrm{MHz}, \mathrm{CDCl}_{3}\right.$, Cambridge Isotope Laboratories): $3.87-3.58\left(\mathrm{~m}, 3 \mathrm{H}, \mathrm{H} 1+\mathrm{C}_{2} \mathrm{H}_{2}\right) ; 2.96(\mathrm{~d}, 1 \mathrm{H}$, $\left.J=4.6 \mathrm{~Hz}, \mathrm{Cl}^{\prime} \mathrm{H}_{2}\right) ; 2.65\left(\mathrm{~d}, 1 \mathrm{H}, J=4.6 \mathrm{~Hz}, \mathrm{Cl}^{\prime} \mathrm{H}_{2}\right) ; 1.38$ (s, $3 \mathrm{H}, \mathrm{CH}_{3}$ ) ppm (Fig. S1). ${ }^{13} \mathrm{C} \mathrm{NMR}\left(100 \mathrm{MHz}, \mathrm{CDCl}_{3}\right)$ : 72.4, 63.5, 57.3, 50.6, $18.5 \mathrm{ppm}$ (Fig. S2). threo-IEPOX1: ${ }^{1} \mathrm{H}$ NMR $\left(400 \mathrm{MHz}, \mathrm{CDCl}_{3}\right): 3.87-3.58(\mathrm{~m}, 3 \mathrm{H}, \mathrm{H} 1$ $\left.+\mathrm{C}_{2} \mathrm{H}_{2}\right) ; 2.89\left(\mathrm{~d}, 1 \mathrm{H}, J=4.7 \mathrm{~Hz}, \mathrm{Cl}^{\prime} \mathrm{H}_{2}\right) ; 2.63(\mathrm{~d}, 1 \mathrm{H}$, $\left.J=4.7 \mathrm{~Hz}, \mathrm{Cl}^{\prime} \mathrm{H}_{2}\right) ; 1.35$ (s, 3H, $\mathrm{CH}_{3}$ ) ppm (Fig. S1). ${ }^{13} \mathrm{C}$ NMR (100 MHz, $\left.\mathrm{CDCl}_{3}\right)$ : 74.0, 63.7, 58.0, 51.5, $17.43 \mathrm{ppm}$ (Fig. S2).

\subsection{IEPOX-2 (erythro- and threo-2-(oxiran-2-yl) propane-1,2-diol)}

Compound 2 ( $210 \mathrm{mg}, 2 \mathrm{mmol}$ ) was dissolved in water acidified with $\mathrm{HCl}(0.1 \mathrm{~N}, 2 \mathrm{ml}$, Fisher $)$ and the mixture was heated in a water bath at $50^{\circ} \mathrm{C}$ for $30 \mathrm{~min}$ and then lyophilized. The residue was dissolved in acetonitrile (ACN, Fisher) $(5 \mathrm{ml})$, cooled in an ice-water bath and $m$-chloroperoxybenzoic acid ( $m$ CPBA) $(540 \mathrm{mg}, 70 \%$, $2.4 \mathrm{mmol}$, Aldrich) was added. The clear solution was stirred in the ice-water bath for $2 \mathrm{~h}$ and then at RT until transformation of the starting material as monitored by thin layer chromatography (TLC) was complete. The mixture was cooled at $4{ }^{\circ} \mathrm{C}$ and the resulting precipitate separated by filtration to remove the bulk of the 3-chlorobenzoic acid. The filtrate was concentrated under reduced pressure and the residue was purified by flash chromatography $\left(\mathrm{SiO}_{2}\right.$, diethyl ether) to afford IEPOX-2 (150 mg, $62 \%$ ). The ${ }^{1} \mathrm{H}$ NMR spectrum (Fig. S3) is identical to published spectra (Adam and Nestler, 1993; Adam et al., 1997).

\subsection{IEPOX-3 (cis-2-methyl-2,3-epoxy-1,4-butanediol)}

3-Methyl furan-2(5H)-one (7) (2.11 g, $21.5 \mathrm{mmol})$ in diethyl ether $(10 \mathrm{ml})$ was added to a suspension of lithium aluminum hydride (LAH) $(1.02 \mathrm{~g}, 31.6 \mathrm{mmol}$, Aldrich) in diethyl ether $(50 \mathrm{ml})$ at $0{ }^{\circ} \mathrm{C}$. Following the completion of addition, the mixture was stirred at RT for $2 \mathrm{~h}$ and quenched with water $(1 \mathrm{ml})$ followed by the addition of $15 \%(\mathrm{w} / \mathrm{w})$ $\mathrm{NaOH}(1 \mathrm{ml}$, Fisher) and water $(3 \mathrm{ml})$ and stirred at RT for $0.5 \mathrm{~h}$. The organic layer was filtered, then dried with anhydrous $\mathrm{Na}_{2} \mathrm{SO}_{4}$ and concentrated under reduced pressure. 
The residue was purified by chromatography $\left(\mathrm{SiO}_{2}\right.$, hexane (Acros)/diethyl ether, $1: 1)$ to afford 2-methyl-2-butene1,4-diol (8) (0.6 g, $27 \%$ ) (Duvold et al., 1997). ${ }^{1} \mathrm{H}$ NMR $\left(400 \mathrm{MHz}, \mathrm{CDCl}_{3}\right): 5.65(\mathrm{t}, J=7.6 \mathrm{~Hz}, 1 \mathrm{H}), 4.19-4.09(\mathrm{~m}$, 4H), 1.84 (s, 3H) ppm (Fig. S4).

Compound $8(0.6 \mathrm{~g}, 5.9 \mathrm{mmol})$ was dissolved in $\mathrm{ACN}$ $(20 \mathrm{ml})$ and cooled in an ice-water bath. $m$ CPBA (1.6 g, $70 \%, 7.2 \mathrm{mmol}$ ) was added and the clear solution was stirred in the ice-water bath for $2 \mathrm{~h}$ and then at RT until complete transformation of the starting material as monitored by TLC. The mixture was cooled at $4{ }^{\circ} \mathrm{C}$ and the resulting precipitate separated by filtration to remove the bulk of the 3-chlorobenzoic acid. The filtrate was concentrated under reduced pressure and the residue dissolved in water $(20 \mathrm{ml})$ and washed repeatedly with chloroform until no 3chlorobenzoic acid was detected by TLC. The aqueous solution was lyophilized to give IEPOX-3 as colorless oil (488 mg, 70\%). GC/EI-MS: $m / z$ 244, 231, 217, 205, 191, 159, 147. ${ }^{1} \mathrm{H}$ NMR $\left(400 \mathrm{MHz}, \mathrm{D}_{2} \mathrm{O}\right): 3.94(\mathrm{dd}, 1 \mathrm{H}, J=12.2$, $6.0 \mathrm{~Hz}, \mathrm{H} 4), 3.82-3.74(\mathrm{~m}, 2 \mathrm{H}, \mathrm{H} 1$ and $\mathrm{H} 4), 3.68(\mathrm{~d}, 1 \mathrm{H}$, $J=11.9 \mathrm{~Hz}, \mathrm{H} 1), 3.09(\mathrm{t}, 1 \mathrm{H}, J=5.8 \mathrm{~Hz}, \mathrm{H} 3), 1.44(\mathrm{~s}, 3 \mathrm{H}$, $\mathrm{CH}_{3}$ ) ppm (Fig. S5); ${ }^{13} \mathrm{C}$ NMR $\left(100 \mathrm{MHz}, \mathrm{D}_{2} \mathrm{O}\right): 64.4,63.4$, 61.4, 61.1, 20.5 ppm (Fig. S6).

\section{5 trans-4-((t-Butyldimethylsilyl)oxy)-2-methyl-2- buten-1-ol (11)}

$\mathrm{SeO}_{2}(0.85 \mathrm{~g}, 7.7 \mathrm{mmol}$, Aldrich) was added to a solution of $9(3.06 \mathrm{~g}, 16.4 \mathrm{mmol})$ in dichloromethane $(\mathrm{DCM})(100 \mathrm{ml}$, Aldrich) cooled in ice-water. A solution of $t-\mathrm{BuOOH}(3 \mathrm{ml}$, $5.5 \mathrm{M}$ in decane, $16.5 \mathrm{mmol}$, Aldrich) was added and the reaction mixture was stirred at $0^{\circ} \mathrm{C}$ for an additional $2 \mathrm{~h}$ before being warmed to RT and stirred for an additional $1 \mathrm{~h}$ at RT. The reaction was then quenched with saturated $\mathrm{NaHCO}_{3}$ ( $25 \mathrm{ml}$, Fisher), separated and the organic layer washed with brine and evaporated to dryness. The residue was taken up in ethanol (50 ml, Fisher) and cooled in an ice bath. $\mathrm{NaBH}_{4}$ $(0.5 \mathrm{~g}, 9.2 \mathrm{mmol}$, Aldrich) was added portionwise and the reaction mixture stirred for $15 \mathrm{~min}$. Acetone ( $1 \mathrm{ml}$, Acros) was added and the reaction was stirred for another $15 \mathrm{~min}$. Bulk solvent was then removed under reduced pressure; the residue was partitioned between water $(25 \mathrm{ml})$ and ethyl acetate $(50 \mathrm{ml})$, and the aqueous layer extracted with ethyl acetate $(2 \times 25 \mathrm{ml})$. The combined organic extracts were washed with brine, dried over $\mathrm{Na}_{2} \mathrm{SO}_{4}$, filtered and concentrated. The resulting oil was purified by flash chromatography $\left(\mathrm{SiO}_{2}\right.$, hexane/ethyl acetate, $10: 1)$ to give $\mathbf{1 1}(1.76 \mathrm{~g}, 8.7 \mathrm{mmol}$, $53 \%$ over two steps). ${ }^{1} \mathrm{H}$ NMR $\left(400 \mathrm{MHz}, \mathrm{CDCl}_{3}\right): 5.53-$ $5.59(\mathrm{~m}, 1 \mathrm{H}), 4.25(\mathrm{dd}, 2 \mathrm{H}, J=6.3,0.8 \mathrm{~Hz}), 4.03(\mathrm{~d}, 2 \mathrm{H}$, $J=5.2 \mathrm{~Hz}), 1.68(\mathrm{~s}, 3 \mathrm{H}), 0.92(\mathrm{~s}, 9 \mathrm{H}) ; 0.87(\mathrm{~s}, 6 \mathrm{H}) \mathrm{ppm}$ (Fig. S9); ${ }^{13} \mathrm{C}$ NMR $\left(100 \mathrm{MHz}, \mathrm{CDCl}_{3}\right): 136.35,125.44$, $68.49,60.09,26.19,18.62,14.00,4.93 \mathrm{ppm}$.

\section{6 (3-(((t-Butyldimethylsilyl)oxy)methyl)-2- methyloxiran-2-yl)methanol (12)}

Compound $11(0.7 \mathrm{~g}, 3.5 \mathrm{mmol})$ was dissolved in DCM $(20 \mathrm{ml}), m$ CPBA $(0.9 \mathrm{~g}, 77 \%, 3.9 \mathrm{mmol})$ was added and the mixture stirred at RT over night. The reaction mixture was then concentrated under reduced pressure and the residue dissolved in diethyl ether $(80 \mathrm{ml})$ and washed with saturated solutions of $\mathrm{Na}_{2} \mathrm{~S}_{2} \mathrm{O}_{3}, \mathrm{Na}_{2} \mathrm{CO}_{3}$ (Fisher) and brine consecutively, and dried over anhydrous $\mathrm{MgSO}_{4}$ (Fisher). Following filtration and concentration, the residue was purified by chromatography $\left(\mathrm{SiO}_{2}\right.$, hexane/ethyl acetate, $\left.10: 1\right)$ to provide $12 .{ }^{1} \mathrm{H}$ NMR $\left(400 \mathrm{MHz}, \mathrm{CDCl}_{3}\right): 3.82(\mathrm{dd}, 1 \mathrm{H}$, $J=11.7,4.8 \mathrm{~Hz}), 3.76(\mathrm{dd}, 1 \mathrm{H}, J=11.7,5.8 \mathrm{~Hz}), 3.64(\mathrm{dd}$, $2 \mathrm{H}, J=12.6 \mathrm{~Hz}), 3.20(\mathrm{dd}, 1 \mathrm{H}, J=5.7,4.8 \mathrm{~Hz}), 1.30(\mathrm{~s}$, 3H), 0.92 (s, 9H); 0.09 (s, 6H) ppm (Fig. S10).

\subsection{IEPOX-4 (trans-2-methyl-2,3-epoxybutane-1,4-diol)}

Compound 12 was dissolved in tetrahydrofuran (THF) $(6 \mathrm{ml}$, Aldrich), cooled in ice water, then $\mathrm{Bu}_{4} \mathrm{NF}(6 \mathrm{ml}, 1 \mathrm{M}$, Aldrich) was added and the mixture was stirred for $1 \mathrm{~h}$, concentrated and the residue purified by chromatography $\left(\mathrm{SiO}_{2}\right.$, diethyl ether) to afford IEPOX-4 (308 mg, 82\%). GC/EIMS: $24.44 \mathrm{~min} m / z$ 244, 205, 191, 159, 147. ${ }^{1} \mathrm{H}$ NMR $\left(400 \mathrm{MHz}, \mathrm{CDCl}_{3}\right) ; 3.92(\mathrm{dd}, 1 \mathrm{H}, J=12.5,4.5 \mathrm{~Hz}, \mathrm{H} 4)$, $3.75-3.68(\mathrm{~m}, 2 \mathrm{H}, \mathrm{H} 4+\mathrm{H} 1), 3.58$ (d, $1 \mathrm{H}, J=12.6 \mathrm{~Hz}, \mathrm{H} 1)$, 3.28 (dd, $1 \mathrm{H}, J=7.1,4.5 \mathrm{~Hz}, \mathrm{H} 3), 1.36$ (s, $\left.3 \mathrm{H}, \mathrm{CH}_{3}\right) \mathrm{ppm}$ (Fig. S11). ${ }^{13} \mathrm{C}$ NMR $\left(100 \mathrm{MHz}, \mathrm{CDCl}_{3}\right)$ : 65.2, 61.4, 61.1, 59.9, 14.4 ppm (Fig. S12).

\section{8 cis-3-Methyltetrahydrofuran-3,4-diol (14) and trans-3-methyltetrahydrofuran-3,4-diol (15): method 1}

IEPOX-1 (200 mg, $1.7 \mathrm{mmol})$ in water $(4 \mathrm{ml})$ was stirred at $80^{\circ} \mathrm{C}$ for $4 \mathrm{~h}$ with $p$-toluenesulfonic acid $(6 \mathrm{mg}$, Aldrich) to give a mixture of diastereomeric 2-methylbutane tetrols. The reaction mixture was lyophilized and the residue mixed with toluene $(15 \mathrm{ml}$, Fisher) and refluxed overnight. Following removal of the solvent under reduced pressure, the residue was purified by column chromatography $\left(\mathrm{SiO}_{2}\right.$, hexane/diethyl ether, $2: 1$ ) to give $\mathbf{1 4}$ as the early-eluting isomer and $\mathbf{1 5}$ as the late-eluting isomer: $\mathbf{1 4}(25 \mathrm{mg}, 14 \%)$. GC/EIMS: $m / z$ 262, 247, 231, 218, 204, 147. ${ }^{1} \mathrm{H}$ NMR $(400 \mathrm{MHz}$, $\left.\mathrm{CDCl}_{3}\right): 4.04(\mathrm{dd}, 1 \mathrm{H}, J=9.8,5.8 \mathrm{~Hz}, \mathrm{H} 5), 3.92-3.86(\mathrm{~m}$, $1 \mathrm{H}, \mathrm{H} 4), 3.76(\mathrm{~d}, 1 \mathrm{H}, J=9.2 \mathrm{~Hz}, \mathrm{H} 2), 3.73(\mathrm{dd}, 1 \mathrm{H}, J=$ 9.8, 4.3 Hz, H5). 3.62 (d, $1 \mathrm{H}, J=9.2 \mathrm{~Hz}, \mathrm{H} 2), 1.35$ (s, $\left.3 \mathrm{H}, \mathrm{CH}_{3}\right)$ ppm (Fig. S19). ${ }^{13} \mathrm{C}$ NMR $\left(100 \mathrm{MHz}, \mathrm{CDCl}_{3}\right)$ : 77.43, 76.92, 76.50, 73.87, 23.48 ppm (Fig. S20). 15 (49 mg, $29 \%$ ): GC-EIMS. $m / z$ 262, 247, 231, 218, 204, 147. ${ }^{1} \mathrm{H}$ NMR $\left(400 \mathrm{MHz}, \mathrm{D}_{2} \mathrm{O}\right): 4.27(\mathrm{dd}, J=10.1,4.5 \mathrm{~Hz}, 1 \mathrm{H}$, H5), 3.99 (dd, $J=4.6,1.8 \mathrm{~Hz}, 1 \mathrm{H}, \mathrm{H} 4), 3.75-3.68(\mathrm{~m}, 3 \mathrm{H}$, $\mathrm{C} 2 \mathrm{H}_{2}+\mathrm{H} 5$ ), 1.35 (s, 3H, $\mathrm{CH}_{3}$ ) ppm (Fig. S22). ${ }^{13} \mathrm{C}$ NMR 
$\left(100 \mathrm{MHz}, \mathrm{CDCl}_{3}\right): 80.54,79.13,75.26,74.56,18.30 \mathrm{ppm}$ (Fig. S23).

\section{9 cis-3-Methyltetrahydrofuran-3,4-diol (14) and trans-3-methyltetrahydrofuran-3,4-diol (15): method 2}

\subsubsection{4-(Benzyloxy)tetrahydrofuran-3-ol (17)}

1,4-Anhydroerythritol (16) (3.1 g, $29.8 \mathrm{mmol}$, Aldrich) was added to a solution of $\mathrm{Bu}_{2} \mathrm{SnO}(7.6 \mathrm{~g}, 30.5 \mathrm{mmol}$, Aldrich) and $\mathrm{Bu}_{4} \mathrm{NI}(12.2 \mathrm{~g}, 33.1 \mathrm{mmol}$, Aldrich) in toluene $(150 \mathrm{ml})$ and heated at reflux for $1 \mathrm{~h}$. After the reaction mixture was cooled to RT, $\mathrm{BnBr}$ ( $4 \mathrm{ml}, 33.7 \mathrm{mmol}$, Aldrich) was added and the mixture was maintained at $\sim 100^{\circ} \mathrm{C}$ for $4 \mathrm{~h}$ and then cooled to RT. After dilution with diethyl ether, the mixture was washed with aqueous $\mathrm{Na}_{2} \mathrm{~S}_{2} \mathrm{O}_{3}$, water and brine successively and dried over anhydrous $\mathrm{MgSO}_{4}$. The solvent was removed under reduced pressure, and the residue purified by column chromatography $\left(\mathrm{SiO}_{2}\right.$, hexane/ethyl diethyl ether, $2: 1)$ to give $\mathbf{1 7}(5.1 \mathrm{~g}, 88 \%) .{ }^{1} \mathrm{H} \mathrm{NMR}\left(400 \mathrm{MHz}, \mathrm{CDCl}_{3}\right)$ : 7.42-7.28 (m, 5H, phenyl-H), $4.61\left(\mathrm{~s}, 2 \mathrm{H}\right.$, benzyl- $\left.\mathrm{CH}_{2}\right)$ 4.29-4.22 (m, 1H), 4.11-4.04 (m, 1H), 3.93-3.84 (m, 2H), 3.82-3.71 (m, 2H), 2.81-2.74 (m, 1H, OH) ppm (Fig. S15). ${ }^{13} \mathrm{C}$ NMR $\left(100 \mathrm{MHz}, \mathrm{CDCl}_{3}\right): 137.34,128.79,128.37$, 128.06, 78.45, 73.61, 72.74, 70.52, 70.16 ppm (Fig. S16).

\subsubsection{4-(Benzyloxy)dihydrofuran-3(2H)-one (18)}

To a mixture of pyridine $\left(14.0 \mathrm{ml}\right.$, Aldrich) and $\mathrm{Ac}_{2} \mathrm{O}$ $(8.25 \mathrm{ml}$, Aldrich) in DCM $(50 \mathrm{ml})$ cooled in an icewater bath, $\mathrm{CrO}_{3}(8.4 \mathrm{~g}, 84 \mathrm{mmol}$, Aldrich) was added, followed by $17(5.1 \mathrm{~g}, 26.3 \mathrm{mmol})$. The mixture was stirred at RT for $1.5 \mathrm{~h}$, poured in to ethyl acetate $(300 \mathrm{ml})$ and filtered through silica gel. The filtrate was concentrated under reduced pressure and the residue purified by chromatography $\left(\mathrm{SiO}_{2}\right.$, hexane/diethyl ether, 2:1) to give $\mathbf{1 8}(1.4 \mathrm{~g}, 28 \%) .{ }^{1} \mathrm{H}$ NMR (400 MHz, $\left.\mathrm{CDCl}_{3}\right): 7.43-7.29$ (m, 5H, phenyl-H), $4.92(\mathrm{~d}$, $1 \mathrm{H}, J=11.8 \mathrm{~Hz}$, benzyl-CH) $4.68(\mathrm{~d}, 1 \mathrm{H}, J=11.8 \mathrm{~Hz}$, benzyl-CH) $4.29(\mathrm{dd}, 1 \mathrm{H}, J=9.8,7.5 \mathrm{~Hz}), 4.06(\mathrm{t}, 1 \mathrm{H}$, $J=7.5 \mathrm{~Hz}), 4.03,3.98\left(\mathrm{q}, 2 \mathrm{H}, J_{\mathrm{AB}}=17.6 \mathrm{~Hz}, \mathrm{COCH}_{2}\right)$, $3.871\left(\mathrm{dd}, 1 \mathrm{H}, J=9.8,7.6 \mathrm{~Hz}\right.$ ) ppm (Fig. S17). ${ }^{13} \mathrm{C}$ NMR $\left(100 \mathrm{MHz}, \mathrm{CDCl}_{3}\right): 213.07,137.08 .128 .73,129.39,129.32$, 76.22, 72.80, 70.93, 70.18 ppm (Fig. S18).

Compound $\mathbf{1 8}(1.2 \mathrm{~g}, 6.3 \mathrm{mmol})$ was added to a solution of $\mathrm{CH}_{3} \mathrm{MgCl}$ in THF ( $3 \mathrm{M}, 1.5$ eq, Aldrich) cooled in an icewater bath. The reaction mixture was stirred at RT for $1 \mathrm{~h}$, quenched with saturated $\mathrm{NH}_{4} \mathrm{Cl}$ (Aldrich) and diluted with diethyl ether. The organic layer was separated and the aqueous layer extracted with diethyl ether. The combined organic phases were washed with brine and dried over anhydrous $\mathrm{MgSO}_{4}$. After filtration and evaporation of the solvent under reduced pressure, the residue was dissolved in methanol (50 ml, Fisher). Pd-C (10\%, $200 \mathrm{mg}$, Aldrich) was added and the reaction mixture was hydrogenated overnight. The reac-
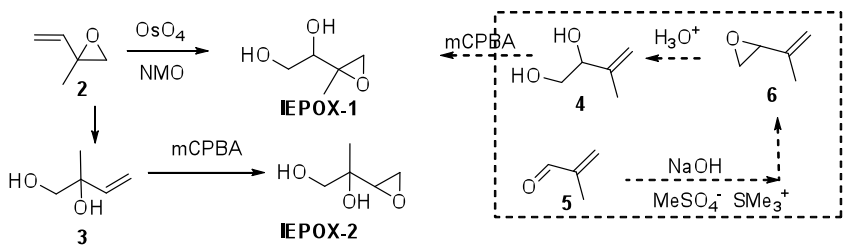

Fig. 2. Scheme for synthesis of IEPOX-1 and IEPOX-2. The scheme within the box represents a multi-step procedure (ColeFilipiak, 2010) for synthesis of IEPOX-1 in lower overall yield than in the present work. (Abbreviations: NMO, $\mathrm{N}$-methylmorpholine oxide; $m$ CPBA, $m$-chloroperbenzoic acid.)

tion mixture was filtered through silica gel, concentrated under reduced pressure and the residue purified by chromatography $\left(\mathrm{SiO}_{2}\right.$, hexane/diethyl ether, $\left.2: 1\right)$ to give $\mathbf{1 4}(190 \mathrm{mg}$, $27 \%$ ) and $\mathbf{1 5}(300 \mathrm{mg}, 41 \%)$. The ${ }^{1} \mathrm{H}$ and ${ }^{13} \mathrm{C}$ NMR spectra were identical to those obtained by method 1 .

\section{Results and discussion}

\subsection{Synthesis}

Syntheses of the mixtures of racemic erythro and threo diastereomers of IEPOX-1 (1-(2-methyloxiran-2-yl)ethane1,2-diol) and IEPOX-2 (2-oxiranyl-propane-1,2-diol) have been reported in different contexts (Cole-Filipiak et al., 2010; Adam et al., 1997; Chiappe et al., 2000), all based on the epoxidation of butendiol $\mathbf{4}$ or $\mathbf{3}$, respectively (Scheme 1). Compound $\mathbf{3}$ is readily available through hydrolysis of commercially available 2-methyl-2-vinyloxirane (2). An excellent yield of a 9:1 erythro/threo mixture of IEPOX-1 has been reported via a titanium-catalyzed epoxidation of precursor 4 (Adam et al., 1997) obtained through hydroxylation of 2-(prop-1-en-2-yl)oxirane (6). Although there are a number of methods for the preparation of $\mathbf{6}$, including catalytic epoxidation of isoprene (Sheng and Zajacek, 1970; Brill and Indictor, 1964; Indictor et al., 1965; Rasmussen et al., 1995), methylene addition to methacrolein (Welzel et al., 1987; Harwood et al., 1990), and a multi-step pathway starting from isoprene (Suzuki et al., 1986), these routes all suffer from poor yield and lack of convenience, limiting the overall yield for the preparation of IEPOX-1. Using 2 as starting material, we have designed a convergent synthesis for IEPOX-1 and IEPOX-2 as diastereomeric mixtures (Fig. 2) which significantly simplifies preparation and improves overall yields. IEPOX-1 was obtained as a mixture of diastereomers in $68 \%$ yield through direct dihydroxylation of 2 with $\mathrm{OsO}_{4}$. Acid hydrolysis of $\mathbf{2}$ followed by epoxidation with $m$ CPBA gave the diastereomeric mixture IEPOX-2 in $62 \%$ yield. The ${ }^{1} \mathrm{H}$ NMR spectrum of IEPOX-1 is identical to published spectra (Chiappe et al., 2000; Adam and Nestler, 1993) in which assignment of NMR signals was based on the spectral characteristics of close structural analogs (Adam 


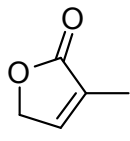

7
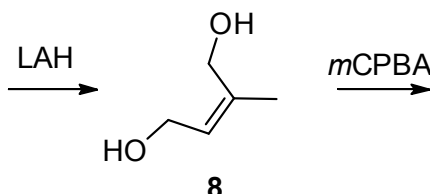

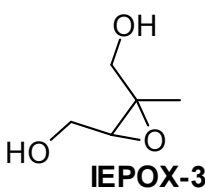

Fig. 3. Scheme for synthesis of IEPOX-3. (Abbreviation: LAH, lithium aluminium hydride.)

and Nestler, 1993). In the ${ }^{13} \mathrm{C}$ NMR spectrum of IEPOX-1, two sets of signals in a $2: 1$ ratio are assigned to the erythro and threo diastereomers, respectively, based on the ${ }^{13} \mathrm{C}$ NMR shifts which are in accord with the published report. Correspondingly, in the ${ }^{1} \mathrm{H}$ NMR, the resolved signals with higher intensity were assigned to erythro diastereomer. For IEPOX2, the ${ }^{1} \mathrm{H}$ NMR spectrum of the mixture was identical to the reported spectrum in which, however, the erythro and threo diastereomers were not assigned. The tentative assignment for the two sets of NMR signals to erythro and threo diastereomers in this work is based on the NMR spectrum of the close structural analog linalool epoxide for which the absolute stereochemistry has been established (Morales et al., 2011; Khomenko et al., 2002).

Synthesis of a mixture of IEPOX-3 and IEPOX-4 in 11\% overall yield starting with isoprene has been reported (ColeFilipiak et al., 2010). Since the authors did not specify that their product was a mixture, we have deduced the composition by comparison of the published ${ }^{1} \mathrm{H}$ NMR spectrum with the ${ }^{1} \mathrm{H}$ NMR spectra of the racemates of the pure geometric isomers from our syntheses described below. The cis isomer IEPOX-3 was prepared by the unambiguous pathway shown in Fig. 3. Commercially available 3-methyl furan-2(5H)-one (7) was reduced with LAH to afford cis-2-methyl-2-butene1,4-diol (8), which was then epoxidized with $m$ CPBA to give IEPOX-3. While some over-reduction of 7 to the corresponding butanediol appears difficult to avoid, isolation of $\mathbf{8}$ could be achieved through chromatographic separation. To ensure the purity of the target IEPOX-3, the fully reduced butanediol side product was more efficiently removed following treatment of $\mathbf{7}$ with $\mathrm{LAH}$, rather than following the epoxidation. The overall yield for this sequence was $19 \%$, further optimization was not attempted. The cis geometry of IEPOX-3 was confirmed by 1D nuclear Overhauser effect spectroscopy (1D NOESY) (Fig. S8), which showed strong dipolar coupling between the methyl group and the oxirane proton.

IEPOX-4 was prepared according to the scheme in Fig. 4. 3-Methyl-2-buten-1-ol (9) was protected with TBDMS and a hydroxyl group introduced by $\mathrm{SeO}_{2}$ oxidation followed by reduction with $\mathrm{NaBH}_{4}$. The resulting 2-buten-1-ol (11) was epoxidized and deprotected to give IEPOX-4 in $43 \%$ yield. The trans-configuration was confirmed by the absence of a nuclear Overhauser effect correlation between the methyl group and the oxirane proton in the 1D NOESY spectrum (Fig. S14).

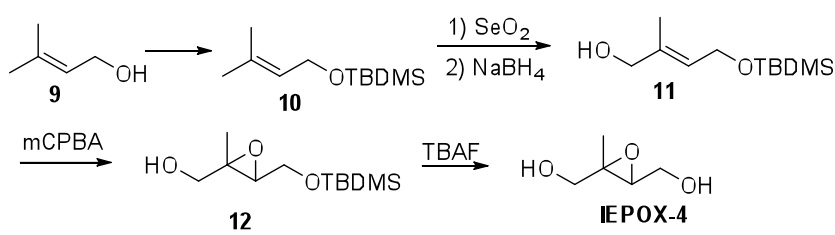

Fig. 4. Scheme for synthesis of IEPOX-4. (Abbreviations: TBDMS, tert-butyldimethylsilyl; TBAF, tetrabutylammonium fluoride.)
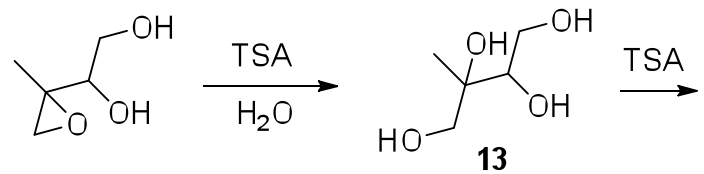

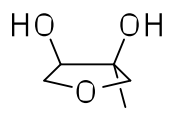

cis- isomer

14

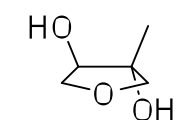

transisomer

15
Fig. 5. Scheme for preparation of a mixture of $\mathbf{1 4}$ and $\mathbf{1 5}$ (method 1). (Abbreviation: TSA, toluenesulfonic acid.)

The preparation of cis-3-methyltetrahydrofuran-3,4-diol (14) has been reported in two steps starting with 4-methyl1,2-dioxine (Robinson et al., 2009). Since this route leads only to the cis isomer and the overall yield, taking into account the photolytic synthesis of the dioxine from isoprene (Motsumoto et al., 1985), is moderate, we devised two routes to a the synthesis of $\mathbf{1 4}$ and $\mathbf{1 5}$ as a readily separable mixture. First, taking advantage of IEPOX-1 on hand, we prepared the mixture according to the scheme in Fig. 5 by acid-catalyzed hydrolysis of IEPOX-1 to the 2-methylerythritol/threitol mixture $\mathbf{1 3}$ followed by a second acidcatalyzed cyclization of $\mathbf{1 3}$ to the desired mixture isolated as the pure targets by column chromatography. It is worth noting that while the process is simple and can be carried out in one-pot, the isolation is complicated by side products. The combined yield for the purified isomers 14 and $\mathbf{1 5}$ ( $1: 2$, respectively) was $43 \%$ starting from IEPOX-1. Alternatively, the isomers $\mathbf{1 4}$ and $\mathbf{1 5}$ can be obtained via the scheme in Fig. 6. Dihydroxytetrahydrofuran 16 was partially protected by benzylation (17) and oxidized to dihydrofuranone 18. The methyl substituent was introduced by a Grignard reaction, and following deprotection, purified isomers 14 and 15 ( $1: 1.6$, respectively) were obtained in a combined yield of $68 \%$ from 18 . Through the latter method, the purification of the final products to a high standard was facilitated.

In the ${ }^{1} \mathrm{H}$ NMR of $\mathbf{1 4}$ and $\mathbf{1 5}$, the signal for $\mathrm{H} 4$ displays a broadened pattern, distinct from other non-exchanging protons, which display well-resolved first order doublet-ofdoublet signal patterns. The ${ }^{1} \mathrm{H}$ NMR of $\mathbf{1 4}$ was identical to 
<smiles>OC1COCC1O</smiles>

16

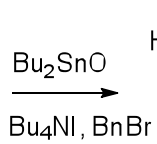$$
17
$$

19

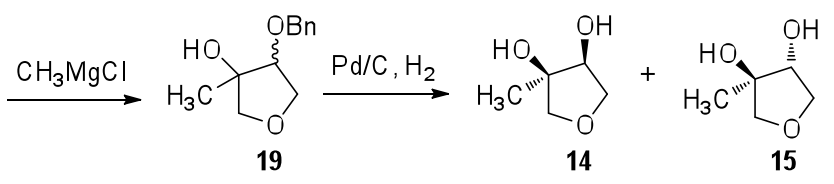

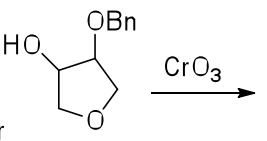

17

14

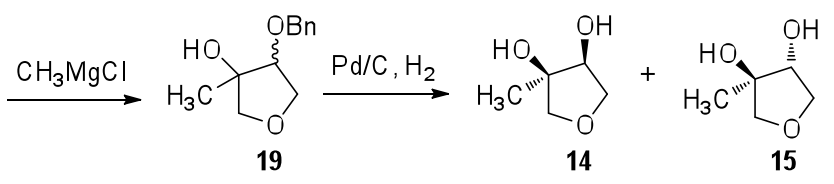<smiles>O=C1COCC1Br</smiles>

18
Fig. 6. Scheme for preparation of a mixture of $\mathbf{1 4}$ and $\mathbf{1 5}$ (method 2). (Abbreviation: $\mathrm{Bu}_{2} \mathrm{SnO}$, dibutyltin oxide; $\mathrm{Bu}_{4} \mathrm{NI}$, tetrabutylammonium iodide; $\mathrm{BnBr}$, benzyl bromide.)

that reported for the cis isomer (Robinson et al., 2009), and the cis-isomeric structure was further confirmed by the 1D NOESY spectrum (Fig. S21), in which the signal for carbinyl $\mathrm{H} 4$ is strongly enhanced on irradiation of the neighboring 3methyl signal. In the case of $\mathbf{1 5}$, irradiation of the methyl signal produces a much smaller enhancement of the $\mathrm{H} 4$ signal in the 1D NOESY spectrum in accordance with expectation for the trans-geometry. The GC/EI-MS of the bis-TMS derivatives of $\mathbf{1 4}$ and $\mathbf{1 5}$ provides additional evidence supporting the assignment of $\mathbf{1 4}$ as the cis isomer. Fragmentation to the product ion $\left[\mathrm{Me}_{3} \mathrm{Si}-\mathrm{O}=\mathrm{SiMe}_{2}\right]^{+}(m / z$ 147) is significantly more pronounced for $\mathbf{1 4}$ than for 15, as would be expected for the cis isomer (Diekman et al., 1968; Pierce et al., 1968).

\subsection{Purity of synthetic targets}

The purity of the IEPOX and 3-methyl-3,4dihydroxytetrahydrofuran isomers was evaluated by both the GC/EI-MS spectra and total ion chromatograms (TICs) of the TMS-derivatized standards and the ${ }^{1} \mathrm{H}$ - and ${ }^{13} \mathrm{C}$ NMR traces. The TICs and GC/EI-MS spectra of the TMS-derivatized standards demonstrate high purity (Lin et al., 2012). No extraneous resonances were observed in the NMR spectra. Since a proton signal integrating to $>1 \%$ of a proton signal of the target compounds would have been detectable in the NMR spectra, the targets were isolated in $>99 \%$ purity.

\subsection{Stability of stock solutions}

The stability of the isomeric IEPOX and tetrahydrofuran isomers is of interest with regard to the preparation and storage of stock solutions. Stock solutions of IEPOX-1, IEPOX3 and the THF isomers in ethyl acetate $\left(100 \mathrm{ng} \mathrm{\mu l}^{-1}\right)$ were prepared and stored at $-20^{\circ} \mathrm{C}$ for use in chamber experiments and as standards. Over a period of $1 \mathrm{yr}$, no deterioration was observed for any of the compounds in analyses of the stock solutions by derivatization GC/EI-MS (Figs. S26, S27). Thus, both the IEPOX and THF isomers can be stored for long periods at subambient temperature in an aprotic solvent.

\section{Conclusions}

We have reported convenient synthetic routes to the IEPOX isomers that are key intermediates in the formation of isoprene-derived SOA, as well as to the 3-methyl-3,4dihydroxytetrahydrofuran isomers that are the initial rearrangement products of IEPOX on contact with acidic seed aerosols. The availability of these compounds will be critical in further investigation into the influence of environmental conditions on SOA formation and composition and will also be important in assessing the impact of isoprene SOA on human health.

\section{Supplementary material related to this article is available online at: http://www.atmos-chem-phys.net/12/ 8529/2012/acp-12-8529-2012-supplement.pdf.}

Acknowledgements. This research was supported in part by a grant from the National Institute of Environmental Health Sciences (P30ES010126). Y.-H. Lin and J. D. Surratt were supported in part by the Electric Power Research Institute (EPRI). H. Zhang was supported in part by a USA EPA contract (EP-W-09-023).

Edited by: F. Keutsch

\section{References}

Adam, W. and Nestler, B.: Direct epoxy hydroxylation of hydroperoxy homoallylic alcohols: multidentate oxygen donor and oxygen acceptor substrates in titanium(IV)-catalyzed epoxidations, J. Am. Chem. Soc., 115, 7226-7231, 1993.

Adam, W., Peters, K., and Renz, M.: Titanium-catalyzed diastereoselective epoxidations of ene diols and allylic alcohols with betahydroperoxy alcohols as novel oxygen donors, J. Org. Chem., 62, 3183-3189, 1997.

Brill, W. F. and Indictor, N.: Reactions of $t$-butyl hydroperoxide with olefins, J. Org. Chem., 29, 710-713, 1964.

Carlton, A. G., Wiedinmyer, C., and Kroll, J. H.: A review of Secondary Organic Aerosol (SOA) formation from isoprene, Atmos. Chem. Phys., 9, 4987-5005, doi:10.5194/acp-9-4987-2009, 2009.

Chan, M. N., Surratt, J. D., Claeys, M., Edgerton, E. S., Tanner, R. L., Shaw, S. L., Zheng, M., Knipping, E. M., Eddingsaas, N. C., Wennberg, P. O., and Seinfeld, J. H.: Characterization and quantification of isoprene-derived epoxydiols in ambient aerosol in the southeastern United States, Environ. Sci. Technol., 44, 45904596, 2010.

Chiappe, C., De Rubertis, A., Tinagli, V., Amato, G., and Gervasi, P. G.: Stereochemical course of the biotransformation of isoprene monoepoxides and of the corresponding diols with liver microsomes from control and induced rats, Chem. Res. Toxicol., 13, 831-838, 2000.

Claeys, M., Graham, B., Vas, G., Wang, W., Vermeylen, R., Pashynska, V., Cafmeyer, J., Guyon, P., Andreae, M. O., Artaxo, P., and Maenhaut, W.: Formation of secondary organic aerosols through photooxidation of isoprene, Science, 303, 1173-1176, 2004. 
Cole-Filipiak, N. C., O'Connor, A. E., and Elrod, M. J.: Kinetics of the hydrolysis of atmospherically relevant isoprene-derived hydroxy epoxides, Environ. Sci. Technol. 44, 6718-6723, 2010.

Diekman, J., Thomson, J. B., and Djerassi, C.: Mass spectrometry in structural and stereochemical problems. CLV. Electron impact induced fragmentations and rearrangements of some trimethylsilyl ethers of aliphatic glycols, and related compounds, J. Org. Chem., 33, 2271-2284, 1968.

Duvold, T., Cali, P., Bravo, J.-M., and Rohmer, M.: Incorporation of 2-C-methyl-D-erythritol, a putative isoprenoid precursor in the mevalonate-independent pathway, into ubiquinone and menaqunone of Escherichia coli, Tetrahedron Lett., 38, 61816184, 1997.

Eddingsaas, N. C., VanderVelde D. G., and Wennberg, P. O.: Kinetics and products of the acid-catalyzed ring-opening of atmospherically relevant butyl epoxy alcohols, J. Phys. Chem. A, 114, 8106-8113, 2010.

Guenther, A., Karl, T., Harley, P., Wiedinmyer, C., Palmer, P. I., and Geron, C.: Estimates of global terrestrial isoprene emissions using MEGAN (Model of Emissions of Gases and Aerosols from Nature), Atmos. Chem. Phys., 6, 3181-3210, doi:10.5194/acp-63181-2006, 2006.

Harwood, L. M., Casy, G., and Sherlock, J.: A simple laboratory procedure for preparation of (1-methylethenyl)oxirane $(3,4-$ epoxyisoprene), Synthetic. Commun., 20, 1287-1291, 1990.

Indictor, N. and Brill, W. F.: Metal Acetylacetonate catalyzed epoxidation of olefins with t-butyl hydroperoxide, J. Org. Chem., 30, 2074-2075, 1965.

Khomenko, T. M., Tatarova, L. E., Korchagina, D. V., and Barkhash, V. A.: Rearrangements of epoxides of linalool and nerolidyl acetate in acid media, Russ. J. Org. Chem., 38, 498-506, 2002.

Lin, Y.-H., Zhang, Z., Docherty, K. S., Zhang, H., Budisulistiorini, S. H., Rubitschun, C. L., Shaw, S., Knipping, E., Edgerton, E. S., Kleindienst, T. E., Gold, A., and Surratt, J. D.: Isoprene epoxydiols as precursors to secondary organic aerosol formation: acidcatalyzed reactive uptake studies with authentic standards, Environ. Sci. Technol., 46, 250-258, 2012.

Matsumoto, M., Dobashi, S., Kuroda, K., and Kondo, K.: Sensitized photo-oxygenation of acyclic conjugated dienes, Tetrahedron, 41, 2147-2154, 1985.
Morales, C. P., Catalan, J., Domingo, V., Delgado, J. A. G., Dobado, J. A., Herrador, M. M., del Moral, J. F. Q., and Barrero, A. F.: Protecting-group-free synthesis of chokols, J. Org. Chem., 76, 2494-2501, 2011.

Paulot, F., Crounse J. D., Kjaergaard, H. G., Kürten, A., St Clair, J. M., Seinfeld, J. H., and Wennberg, P. O.: Unexpected epoxide formation in the gas-phase photooxidation of isoprene, Science, 325, 730-733, 2009.

Pierce, A. E.: Silylation of organic compounds, Pierce Chemical Co., Rockford, 7-26, 1968.

Pope III, C. A. and Dockery, D. W.: Health effects of fine particulate air pollution: lines that connect, J. Air Waste Manage., 56, 709742, 2006.

Rasmussen, K. G., Thomsen, D. S., and Joergensen, K. A.: Regioand enantio-selective catalytic epoxidation of conjugated dienes, J. Chem. Soc. Perk. T. (now Org. Biomol. Chem.), 16, 20092017, 1995.

Robinson, T. V., Pedersen, D. S., Taylor, D. K., and Tiekink, E. R. T.: Dihydroxylation of 4-substituted 1,2-dioxines: a concise route to branched erythro sugars, J. Org. Chem., 74, 5093-5096, 2009.

Sheng, M. N. and Zajacek, J. G.: Hydroperoxide oxidations catalyzed by metals. III. Epoxidation of dienes and olefins with functional groups, J. Org. Chem., 35, 1839-1843, 1970.

Surratt, J. D., Chan, A. W. H., Eddingsaas, N. C., Chan, M. N., Loza, C. L., Kwan, A. J., Hersey, S. P., Flagan, R. C., Wennberg, P. O., and Seinfeld, J. H.: Reactive intermediates revealed in secondary organic aerosol formation from isoprene, P. Natl. Acad. Sci. USA, 107, 6640-6645, 2010.

Suzuki, S., Fujita, Y., Kobayashi, Y., and Sato, F.: A convenient preparative route to 1,2-epoxy-3-methyl-3-butene via ene-type chlorination, Synthetic. Commun., 16, 491-497, 1986.

Wang, W., Kourtchev, I., Graham, B., Cafmeyer, J., Maenhaut, W., and Claeys, M.: Characterization of oxygenated derivatives of isoprene related to 2-methyltetrols in Amazonian aerosols using trimethylsilylation and gas chromatography/ion trap mass spectrometry, Rapid Commun. Mass Sp., 19, 1343-1351, 2005.

Welzel, P., Böttger, D., Heinz, U., Said, A. H., Fischer, A., and Adams, E. A.: synthesis of moenocinol from isoprenoid precursors, Pure Appl. Chem., 59, 385-392, 1987. 